\title{
OPTIMALISASI KALSIUM KARBONAT DARI CANGKANG TELUR UNTUK PRODUKSI PASTA KOMPOSIT
}

\author{
Warsy, Sitti Chadijah, dan Waode Rustiah \\ Jurusan Kimia, Fakultas Sains dan Teknologi, UIN Alauddin Makassar \\ Email:warsyms93@gmail.com
}

\begin{abstract}
Egg shell is a household waste which can be used to produce a composite paste, as it contains around $90 \%$ calsium carbonate $\left(\mathrm{CaCO}_{3}\right)$ as the main composition. This research aims to determine the optimum weight of egg shell powder in composite paste production. This research is conducted by determining the calsium carbonate content beforehand by EDTA titration and the determination of the contain of calsium by using atomic absorption spectroscopy (AAS), then the determination of the optimum weight of shell powder by varying the shell powder and baking soda. The results of the research that has been done that the content of calsium carbonate in the shell of eggs was $92,57 \%$ and calsium at $28 \%$. While the optimum weight for the shell powder manufacture composite paste which is 3 grams with a ratio of 3,O $(\mathrm{Ca}): 7,0(\mathrm{BS})$, in which the pH obtained is 9. This is in a accordance by SNI that the $\mathrm{pH}$ value of the composite paste is 4,510,5 and is semisolid form.
\end{abstract}

Keyword:egg shell, composite paste

\section{PENDAHULUAN}

Perkembangan teknologi dari zaman ke zaman sangatlah pesat, salah satunya dalam bidang kesehatan. Kesehatan merupakan hal terpenting dalam kehidupan yang harus dijaga. Kesehatan tubuh dapat dipelihara dengan menjaga kebersihan anggota tubuhtermasuk kesehatan gigi dan gusi. Kebersihan gigi dan gusi sangat penting untuk mencegah bau mulut, kanker dan penyakit lainnya sehingga diperlukan pasta komposit untuk membersihkan gigi. Pasta komposit merupakan bahan dasar dari pembuatan pasta gigi yang terdiri dari bahan mineral dari alam seperti serbuk cangkang telur (sumber $\mathrm{Ca}^{2+}$ ), baking soda dan gliserin. Seiring berkembangnya ilmu pengetahuan bahwa pasta juga dapat diperoleh dari bahan alam seperti kalsium karbonat $\left(\mathrm{CaCO}_{3}\right)$ yang diperoleh dari cangkang telur sehingga aman bagi tubuh.

Pemanfaatan limbah terus dilakukan oleh para peneliti. Pemanfaatan limbah ini bertujuan untuk mendapatkan produk yang lebih berguna, produk yang dapat diperbaharui, produk yang dapat meningkatkan nilai jual yang ekonomis dan dapat dimanfaatkan oleh manusia. Selain itu pemanfaatan limbah juga dapat mengurangi pencemaran lingkungan. Salah satu limbah yang banyak 
ditemukan di Indonesia yaitu cangkang telur. Sebagian besar cangkang telur terdiri atas persenyawaan kalsium karbonat (CaCO3) sekitar 90.9\%. Komposisi nutrisi cangkang telur dapat secara lengkap dilihat pada tabel 1.

Tabel 1. Komposisi Nutrisi Cangkang Telur

\begin{tabular}{cc}
\hline Nutrisi & Cangkang telur (\%)berat) \\
\hline Air & $29-35$ \\
Protein & $1,4-4$ \\
Lemak murni & $0,10-0,20$ \\
Abu & $89,9-91,1$ \\
Kalsium & $35,1-36,4$ \\
Kalsium karbonat $\left(\mathrm{CaCO}_{3}\right)$ & 90,9 \\
Fosfor & 0,12 \\
Sodium & $0,15-0,17$ \\
Magnesium & $0,37-0,40$ \\
Pottasium & $0,10-0,13$ \\
Sulfur & $0,09-0,19$ \\
Alanin & 0,45 \\
Arginin & $0,56-0,57$ \\
\hline
\end{tabular}

Selain kalsium karbonat yang berfungsi sebagai penguat tulang dan gigi, pembuatan pasta komposit juga menggunakan baking soda yang merupakan salah satu bahan abrasif dalam penambahan pasta gigi yang berguna untuk menghilangkan noda plak, tetapi tidak mengubah warna gigi dan juga bersifat sebagai antibakteri. Penambahan gliserin dalam pembuatan pasta komposit berguna sebagai pelembab agar dapat melembabkan gigi juga mencegah pengeringan dan pengerasan pada pasta.

Berdasarkan penelitian sebelumnya oleh Banani R. Chowdhury, et.al., eds., telah mengembangkanbeberapa bahan makananumumdanbahan limbahyangdapatmenggantikanbahan kimia berbahayaataumahalsepertiasam sitrat, pewarnadanpengawet yangmembuatpasta gigiekonomislebih layakdaripadapasta gigikomersial. Pasta gigiyang mengandungbahan alami danbahan limbahyang digunakan yaitubaking soda(pemutih gigi), bubuk kulit telur(sumberCa ${ }^{2+}$ ), gliserin(pengawet). Namun dalam penelitiannya tidak menunjukkan berat optimum bahan tersebut. Oleh karena itu dilakukan penelitian ini untuk menentukan berat optimum $\mathrm{CaCO}_{3}$, sehingga dapat mempermudah dalam membuat pasta gigi sendiri dirumah dengan mengetahui 
komposisi yang benar. Adapun syarat dalam pembuatan pasta gigi menurut SNI yaitu:

1. Menyegarkan mulut.

2. Tidak berbahaya, lembut dan cocok untuk digunakan.

3. Stabil selama penyimpanan.

Tabel 2. Syarat Mutu Pasta Gigi

\begin{tabular}{|c|c|c|c|}
\hline No & Jenis Uji & Satuan & Syarat \\
\hline 1 & $\begin{array}{l}\text { Sukrosa atau karbohidrat lain } \\
\text { yang dapat terfermentasi }\end{array}$ & - & Negatif \\
\hline 2. & $\mathrm{pH}$ & - & $4,5-10,5$ \\
\hline \multirow{4}{*}{3.} & Cemaran logam & & \\
\hline & $\mathrm{Pb}$ & Ppm & Maksimal 5,0 \\
\hline & $\mathrm{Hg}$ & Ppm & Maksimal 0,02 \\
\hline & As & Ppm & Maksimal 2,0 \\
\hline \multirow{3}{*}{4.} & Cemaran mikroba & & \\
\hline & Angka lempeng total & - & $<10^{5}$ \\
\hline & E. Coli & - & Negatif \\
\hline 5. & Zat pengawet & & $\begin{array}{l}\text { Sesuai dengan yang } \\
\text { diizinkan Dept. Kes }\end{array}$ \\
\hline 6. & $\begin{array}{l}\text { Formaldehida maksimal sebagai } \\
\text { formaldehida bebas }\end{array}$ & $\%$ & 0,1 \\
\hline 7. & Flour bebas & Ppm & $800-1500$ \\
\hline \multirow[t]{2}{*}{8.} & Zat warna & - & $\begin{array}{l}\text { Sesuai dengan yang } \\
\text { diizinkan Dept. Kes }\end{array}$ \\
\hline & Organoleptik & & \\
\hline \multirow[t]{2}{*}{9.} & Keadaan & & $\begin{array}{l}\text { Harus lembut, homogen, } \\
\text { tidak terlihat adanya } \\
\text { gelembug udara, } \\
\text { gumpalan dan partikel } \\
\text { yang terpisah. }\end{array}$ \\
\hline & Benda asing & & Tidak tampak \\
\hline
\end{tabular}




\section{METODE PENELITIAN}

Alat

Alat-alat yang digunakan pada penelitian ini yaituspekrofotometer serapan atom varian AA240 FS, neraca analitik, oven, hot plate, ayakan, buret asam $50 \mathrm{~mL}$, mortal dan alu, statif dan klem, labu takar $500 \mathrm{~mL}, 250 \mathrm{~mL}, 100$ $\mathrm{mL}$ dan $25 \mathrm{~mL}$, gelas kimia $1000 \mathrm{~mL}, 500 \mathrm{~mL}, 250 \mathrm{~mL}$ dan $100 \mathrm{~mL}$, erlenmeyer $300 \mathrm{~mL}$, pipet volume $25 \mathrm{~mL}$, pipet skala $10 \mathrm{~mL}$ dan $5 \mathrm{~mL}$, termometer, batang pengaduk, bulp, botol semprot dan gelas plastik.

\section{Bahan}

Bahan yang digunakan pada percobaan ini adalah air $\left(\mathrm{H}_{2} \mathrm{O}\right)$, amonium hidroksida $\left(\mathrm{NH}_{4} \mathrm{OH}\right)$ p.a, amonium klorida $\left(\mathrm{NH}_{4} \mathrm{Cl}\right)$, aquabides $\left(\mathrm{H}_{2} \mathrm{O}\right)$, aqua DEM $\left(\mathrm{H}_{2} \mathrm{O}\right)$, asam klorida $(\mathrm{HCl}) 6 \mathrm{M}$, asam nitrat $\left(\mathrm{HNO}_{3}\right)$ p.a, asam perklorat $\left(\mathrm{HClO}_{4}\right)$ p.a, baking soda $\left(\mathrm{NaHCO}_{3}\right)$, cangkang telur ayam ras, dinatrium etilen diamin tetra asetat $\left(\mathrm{Na}_{2} \mathrm{EDTA}\right)$, gliserin, indikator murexid, indikator eriochrom black $\mathrm{T}$ (EBT), kertas $\mathrm{pH}$, kertas whatman no. 42, magnesium sulfat $\left(\mathrm{MgSO}_{4} .7 \mathrm{H}_{2} \mathrm{O}\right)$, dan natrium hidroksida $(\mathrm{NaOH}) 4 \mathrm{M}$.

\section{ProsedurKerja}

\section{Pembuatan Serbuk Cangkang Telur (Kalsium Karbonat)}

Cangkang telur dibersihkan dan direndam dengan menggunakan air panas. Kemudian, dikeringkan dalam oven pada suhu $105^{\circ} \mathrm{C}$ selama 30 menit. Setelah itu, cangkang telur dihaluskan dengan menggunakan mortal dan alu sampai menjadi serbuk yang halus. Lalu, serbuk cangkang telur diayak dengan ukuran 100 mesh.

\section{Penentuan Kadar Kalsium Karbonat ( $\left.\mathrm{CaCO}_{3}\right)$ dengan cara Titrasi EDTA}

Pembakuan Etilen Diamin Tetra Asetat (EDTA)

Larutan $\mathrm{Na}_{2}$ EDTA $0,01 \mathrm{M}$ dipipet sebanyak $50 \mathrm{~mL}$ ke dalam buret asam dan padatan $\mathrm{MgSO}_{4} .7 \mathrm{H}_{2} \mathrm{O}$ ditimbang sebanyak 0,6 gram dan dilarutkan dengan aquabides ke dalam labu takar $250 \mathrm{~mL}$. Kemudian dipipet $25 \mathrm{~mL}$ dan dimasukkan ke dalam erlenmeyer. Lalu, ditambahkan $10 \mathrm{~mL}$ buffer $\mathrm{pH} 10$ dan sedikit indikator murexid. Setelah itu, dititrasi dengan larutan $\mathrm{Na}_{2}$ EDTA 0,01 M hingga berwarna biru. Kemudian volume titran dicatat.

\section{Penentuan kadar $\mathrm{CaCO}_{3}$}

Ditimbang \pm 3 gram serbuk cangkang telur dalam gelas kimia $250 \mathrm{~mL}$. Kemudian ditambahkan aqua DM dan $50 \mathrm{~mL} \mathrm{HCl} 6 \mathrm{M}$ sambil diaduk. Larutan dipanaskan sampai $50 \mathrm{~mL}$ dan diaduk hingga larut, kemudian didinginkan. 
Larutan disaring dan diencerkan hingga tanda batas pada labu takar $250 \mathrm{~mL}$. Larutan dipipet $25 \mathrm{~mL}$ ke dalam labu takar $100 \mathrm{~mL}$ dan diencerkan hingga tanda batas. Kemudian larutan dipipet $5 \mathrm{~mL}$ ke dalam erlenmeyer. Lalu, ditambahkan $50 \mathrm{~mL}$ aqua DEM, $2 \mathrm{~mL}$ larutan $\mathrm{NaOH} 4 \mathrm{M}$ dan indikator murexid/ $\mathrm{NaCl}$. Larutan dititrasi dengan larutan baku EDTA hingga berwarna ungu kebiruan. Volume titran dicatat dan dihitung kadar kalsium karbonatnya.

\section{Penentuan Kadar Kalsium Pada Cangkang Telur Menggunakan SSA}

Serbuk cangkang telur ditimbang \pm 1 gram, lalu ditambahkan aquabides sebanyak $50 \mathrm{~mL}$ dan asam nitrat $\left(\mathrm{HNO}_{3}\right)$ p.a sebanyak 5 mL.Kemudian, ditambahkan batu didih dan dipanaskan sampai volume $20 \mathrm{~mL}$, lalu didinginkan.Setelah itu, ditambahkan $1 \mathrm{~mL}$ asam perklorat $\left(\mathrm{HClO}_{4}\right)$ p.a dan dipanaskan kembali sampai menghasilkan uap putih, kemudian didinginkan.Setelah itu, disaring menggunakan kertas whatman no. 42 ke dalam labu takar 100 mL.Larutan standar dibuat dengan konsentrasi 100, 250, 400, 550 dan 700 ppm. Caranya larutan induk 1000 ppm dipipet masing-masing 10, 25, 40, 55 dan $70 \mathrm{~mL}$ ke dalam labu takar $100 \mathrm{~mL}$ dan diencerkan dengan aquabides $\left(\mathrm{H}_{2} \mathrm{O}\right)$ sampai tanda batas.Absorbansi diukur dengan menggunakan spekrofotometer serapan atom (SSA) pada panjang gelombang 239,9 $\mathrm{nm}$. Setelah itu, absorbansinya dicatat dan dihitung kadar kalsiumnya.

\section{Penentuan Berat Optimum Serbuk Cangkang Telur dan Baking Soda dalam Produksi Pasta Komposit}

Serbuk cangkang ditimbang masing-masing sebanyak 0,$5 ; 1,0 ; 1,5 ; 3,0$ dan 5,0 gram. Kemudian kalsium karbonat dicampur dengan baking soda secara berurutan sebanyak 1,0; 3,0; 5,0; 7,0 dan 9,0 gram. Lalu ditambahkan gliserin ke dalam campuran sebanyak $4 \mathrm{~mL}$. Diaduk sampai rata selama 10 menit. Setelah itu, dilakukan uji $\mathrm{pH}$ menggunakan kertas $\mathrm{pH}$ sebelum didiamkan selama 2 minggu. Kemudian dilakukan uji $\mathrm{pH}$ kembali setelah 2 minggu dan diamati.

\section{HASIL DAN PEMBAHASAN}

Pada penelitian ini dilakukan untuk menentukan berat optimum kalsium karbonat dan baking soda dalam produksi pasta komposit. Kalsium karbonat diperoleh dari cangkang telur ayam ras yang ditumbuk halus dengan ukuran partikel 100 mesh. Kemudian ditentukan kalsium karbonat $\left(\mathrm{CaCO}_{3}\right)$ dengan cara titrasi dengan EDTA. 


\section{Penentuan Kadar Kalsium Karbonat (CaCO$)_{3}$ ) dengan Cara Titrasi EDTA}

Penentuan kadar kalsium karbonat pada cangkang telur dilakukan dengan cara titrasi EDTA karena ion kalsium dapat membentuk kompleks dengan EDTA. EDTA termasuk senyawa yang mudah rusak sehingga dilakukan pembakuan EDTA terlebih dahulu untuk mendapatkan konsentrasi EDTA yang sebenarnya. Setelah titrasi hasil yang diperoleh untuk volume EDTA dapat dilihat pada tabel 3. sehingga hasil yang diperoleh dapat dihitung konsentrasi EDTA yang sebenarnya dengan menggunakan rumus pengenceran yaitu sebesar 0,0199 M.

Tabel 3.Titrasi Pembakuan EDTA

\begin{tabular}{cccc}
\hline No. & V MgSO $\mathbf{4}_{\mathbf{4}} \mathbf{7 H _ { 2 }} \mathbf{O}(\mathbf{m L})$ & V EDTA $(\mathbf{m L})$ & M EDTA \\
\hline 1. & 25 & 25,1 & 0,0199 \\
\hline
\end{tabular}

Setelah diperoleh konsentrasi EDTA yang sebenarnya, maka dilanjutkan dengan titrasi penentuan kadar $\mathrm{CaCO}_{3}$ dalam cangkang telur, dimana hasil yang diperoleh dapat dilihat pada tabel 4. Dari hasil volume EDTA yang dihasilkan maka dapat dihitung konsentrasi kalsium karbonat yaitu sebesar $0,0541 \mathrm{~mol} / \mathrm{L}$. Setelah didapat konsentrasi kalsium karbonat maka dapat pula dihitung persentasenya yaitu sebesar 92,57 \%. Dari hasil perhitungan tersebut bahwa kandungan kalsium karbonat pada cangkang telur sangat tinggi sehingga dapat digunakan sebagai bahan dasar dalam pembuatan pasta komposit.

Tabel 4. Titrasi Penentuan $\mathrm{Kadar} \mathrm{CaCO}_{3}$ dalam Cangkang Telur

\begin{tabular}{ccccc}
\hline No. & V Sampel & V EDTA $(\mathbf{m L})$ & $\mathbf{M ~ C a C O}_{\mathbf{3}}$ & $\mathbf{\% ~}_{\mathbf{C a C O}}$ \\
\hline 1. & 57 & 13,6 & 0,0541 & 92,57 \\
\hline
\end{tabular}

\section{Penentuan Kadar Kalsium dengan Menggunakan SSA}

Setelah mendapatkan kadar kalsium karbonat pada cangkang telur yaitu sekitar 92,57 \%, maka dilanjutkan dengan penentuan kadar kalsium pada kalsium karbonat. Untuk dapat menentukan kadar $\mathrm{Ca}^{2+}$ dalam sampel, maka larutan standar harus dibuat dengan konsentrasi yang beragam yaitu 100, 250, 400, 550 dan 700 ppm yang dimaksudkan bahwa pada salah satu konsentrasi dari larutan standar yang dibuat sama atau mendekati dengan konsentrasi sampel tersebut. Setelah itu, larutan standar dan sampel diukur pada panjang gelombang 239,9 nm. Persamaan kurva standar kalsium yang dihasilkan adalah 
$\mathrm{y}=0,00867 \pm 0,0006 \mathrm{x}$ dengan $\mathrm{R}^{2}=0,9978$. Hasil dari penelitian ini dapat dilihat sebagai berikut:

Tabel 5.Data Hasil Pengukuran Absorbansi Larutan Standar Kalsium $\left(\mathrm{Ca}^{2+}\right)$ pada Panjang Gelombang 239,9 nm

\begin{tabular}{ccrcc}
\hline No. & Kode standar & Konsentrasi (x) & Absorban $(\mathbf{y})$ \\
\hline 1. & Blanko & 0 & $\mathrm{ppm}$ & 0,0019 \\
2. & Standar 1 & $100 \mathrm{ppm}$ & 0,0687 \\
3. & Standar 2 & 250 & $\mathrm{ppm}$ & 0,1587 \\
4. & Standar 3 & 400 & $\mathrm{ppm}$ & 0,2487 \\
5. & Standar 4 & 550 & $\mathrm{ppm}$ & 0,3387 \\
6. & Standar 5 & 700 & $\mathrm{ppm}$ & 0,4287 \\
\hline
\end{tabular}

Hubungan antara variasi konsentrasi larutan standar dan absorbansinya dapat dilihat pada gambar 1 .

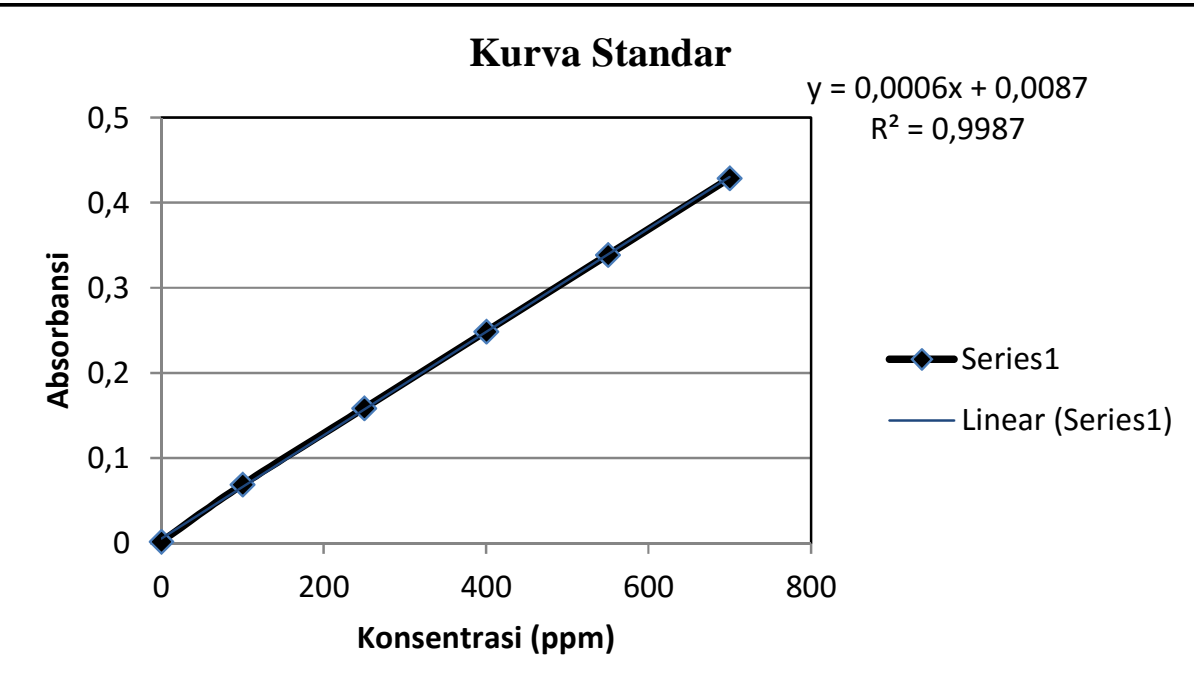

Gambar 1. Grafik Hubungan antara Konsentrasi dengan Daya Adsorpsi Larutan Standar Kalsium $\left(\mathrm{Ca}^{2+}\right)$

Pengukuran kalsium pada sampel dilakukan sebanyak 2 kali, dimana hasil absorbansi yang diperoleh dapat dilihat pada tabel 6. Dari hasil absorbansi yang diperoleh, maka dapat dihitung konsentrasi $\mathrm{Ca}^{2+}$ pada sampel dengan menghubungkannya dalam persamaan linear. Setelah diperoleh Konsentrasi $\mathrm{Ca}^{2+}$ pada sampel maka dapat pula dihitung persentase kadar kalsium pada serbuk cangkang telur yaitu sebesar $28 \%$. Hasil kadar kalsium pada cangkang 
telur ayam ras yang diperoleh lebih tinggi dibandingkan data yang diperoleh dari laboratorium ilmu nutrisi dan makanan IPB tahun 2008 yaitu sebesar $19,20 \%$.

Tabel 6. Data Konsentrasi Kalsium $\left(\mathrm{Ca}^{2+}\right)$ dalam Sampel Cangkang Telur

\begin{tabular}{cccc}
\hline No & Sampel & Absorbansi & Konsentrasi Ca $\mathbf{C a}^{\mathbf{2 +}}(\mathbf{p p m})$ \\
\hline 1. & Ulangan I & 0,3475 & 564,7167 \\
2. & Ulangan II & 0,3424 & 556,2167 \\
\hline
\end{tabular}

Penentuan Berat Optimum Serbuk Cangkang Telur $\left(\mathrm{CaCO}_{3}\right)$ dan Baking Soda dalam Pembuatan Pasta Komposit

Kalsium karbonat dari cangkang telur digunakan sebagai bahan dasar pembuatan pasta komposit karena kemampuannya dalam mengikat kotoran dan menguatkan gigi.

Tabel 7. Variasi Serbuk Cangkang Telur $\left(\mathrm{CaCO}_{3}\right)$ dan Baking Soda dalam Pembuatan Pasta Komposit

\begin{tabular}{cccc}
\hline No. & $\begin{array}{c}\text { Serbuk cangkang } \\
\left(\mathbf{C a C O}_{3}\right) \text { / gram }\end{array}$ & $\begin{array}{c}\text { Baking soda } \\
(\text { gram })\end{array}$ & $\begin{array}{c}\text { Berat pasta } \\
\text { komposit }(\text { gram })\end{array}$ \\
\hline 1. & 0,5 & 1,0 & 6,63 \\
2. & 1,0 & 1,0 & 7,48 \\
3. & 1,5 & 1,0 & 7,89 \\
4. & 3,0 & 1,0 & 9,8 \\
5. & 5,0 & 1,0 & 11,7 \\
6. & 0,5 & 3,0 & 9,15 \\
7. & 1,0 & 3,0 & 9,95 \\
8. & 1,5 & 3,0 & 10,28 \\
9. & 3,0 & 3,0 & 10,96 \\
10. & 5,0 & 3,0 & 13,62 \\
11. & 0,5 & 5,0 & 11,12 \\
12. & 1,0 & 5,0 & 11,62 \\
13. & 1,5 & 5,0 & 12,11 \\
14. & 3,0 & 5,0 & 13,7 \\
15. & 5,0 & 5,0 & 15,51 \\
16. & 0,5 & 7,0 & 12,69 \\
17. & 1,0 & 7,0 & 13,46 \\
18. & 1,5 & 7,0 & 14,06 \\
\hline
\end{tabular}




\begin{tabular}{llll}
\hline 19. & 3,0 & 7,0 & 15,49 \\
20. & 5,0 & 7,0 & 17,44 \\
21. & 0,5 & 9,0 & 13,77 \\
22. & 1,0 & 9,0 & 15,17 \\
23. & 1,5 & 9,0 & 15,84 \\
24. & 3,0 & 9,0 & 17,09 \\
25. & 5,0 & 9,0 & 19,72 \\
\hline
\end{tabular}

Dari hasil pembuatan pasta komposit di atas dengan variasi masingmasing yang sudah dicampur dengan gliserin masing-masing $4 \mathrm{~mL}$ sebagai pelembab telah di uji $\mathrm{pH}$ dan didapatkan $\mathrm{pH} \mathrm{9,} \mathrm{baik} \mathrm{sebelum} \mathrm{didiamkan}$ maupun setelah didiamkan. Hal ini sesuai ketentuan Standar Nasional Indonesia bahwa nilai $\mathrm{pH}$ pada pasta gigi yaitu 4,5 - 10,5. Setelah di uji $\mathrm{pH}$, maka di amati bentuk dari 25 formula yang membentuk pasta, dimana dari 25 formula tersebut terdapat tiga bagian bentuk yaitu cair, semi padat dan padat. Hasilnya dapat dilihat pada tabel 8 .

Tabel 8. Hasil Pengamatan Variasi Serbuk Cangkang Telur $\left(\mathrm{CaCO}_{3}\right)$ dan Baking Soda dalam Pengeluaran Pasta Komposit dari Tube

\begin{tabular}{|c|c|c|c|}
\hline No. & Kode formula & Gambar & Keterangan \\
\hline 1. & $0,5 \mathrm{Ca} ; 1,0 \mathrm{BS}$ & & Cair \\
\hline 2. & $3,0 \mathrm{Ca} ; 7,0 \mathrm{BS}$ & & Semi padat \\
\hline 3. & $5,0 \mathrm{Ca} ; 9,0 \mathrm{BS}$ & & Padat \\
\hline
\end{tabular}

Keterangan: $\mathrm{Ca}=$ serbuk cangkang telur, $\mathrm{BS}=$ baking soda 
Dari hasil penelitian di atas dapat dilihat terdapat 3 bagian yaitu bagian cair, dimana dalam pembuatan pasta komposit jika bentuknya cair maka akan terlalu cepat keluar dari dalam tube sehingga tidak termasuk syarat dalam pembuatan pasta komposit. Jika bentuknya semi padat maka akan dapat mencegah pengeluaran pasta komposit yang terlalu cepat dari dalam tube dan mampu bertahan pada sikat gigi sehingga masuk dalam syarat pembuatan pasta komposit. Sedangkan jika bentuknya padat maka akan keras pengeluarannya dari dalam tube. Pada optimalisasi baking soda dilakukan variasi masingmasing 1,$0 ; 3,0 ; 5,0 ; 7,0$ dan 9,0 gram. Hasilnya dapat dilihat pada gambar 2. Dimana pada optimalisasi untuk baking soda berada pada komposisi 7 gram atau $45 \%$ yang bentuknya semi padat.

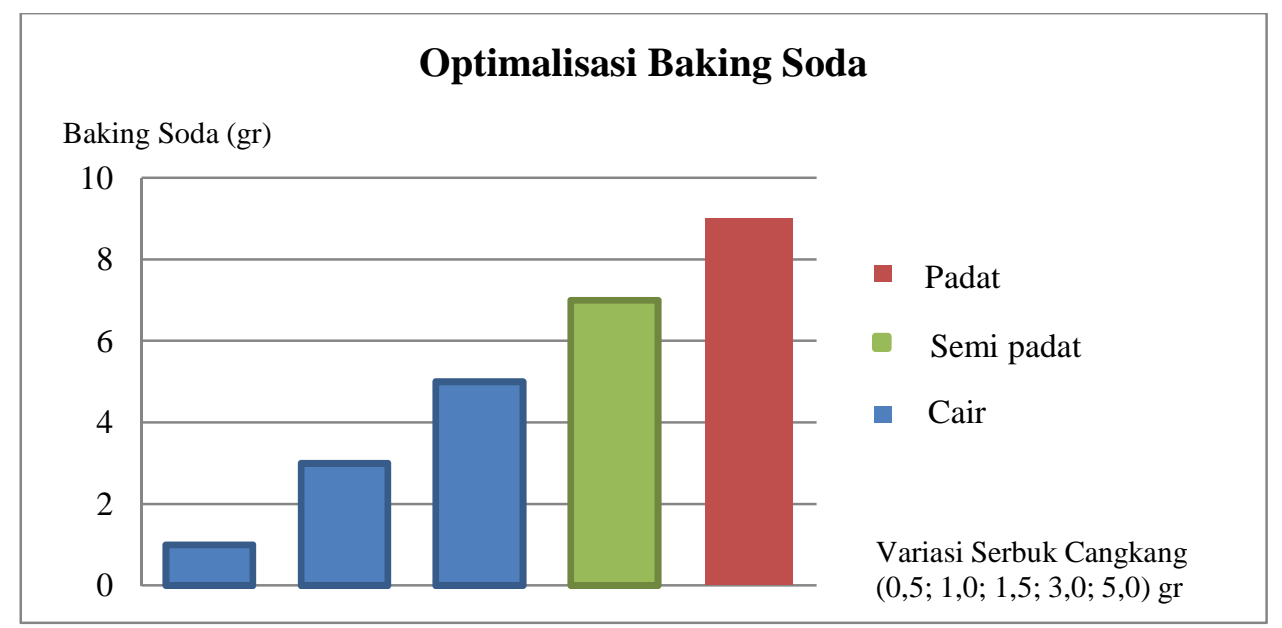

Gambar 2. Optimalisasi Baking Soda dalam Pembuatan Pasta Komposit

Optimalisasi serbuk cangkang (kalsium karbonat) dengan variasi masing-masing 0,$5 ; 1,0 ; 1,5,3,0$ dan 5,0 gram yang dicampur dengan baking soda masing-masing 7 gram dan gliserin masing-masing $4 \mathrm{~mL}$. Hasilnya dapat dilihat pada gambar 4.3. Dimana untuk optimalisasi serbuk cangkang telur (kalsium karbonat) berada pada komposisi 3 gram. Karena bentuknya yang lebih kental dibandingkan dari komposisi serbuk cangkang 0,5; 1,0 dan 1,5 gram. Sedangkan untuk formula 5 gram serbuk cangkang dan 7 gram baking soda pengeluarannya agak padat atau keras, sehingga dapat disimpulkan bahwa berat optimum untuk serbuk cangkang adalah 3 gram atau sekitar $19 \%$. 


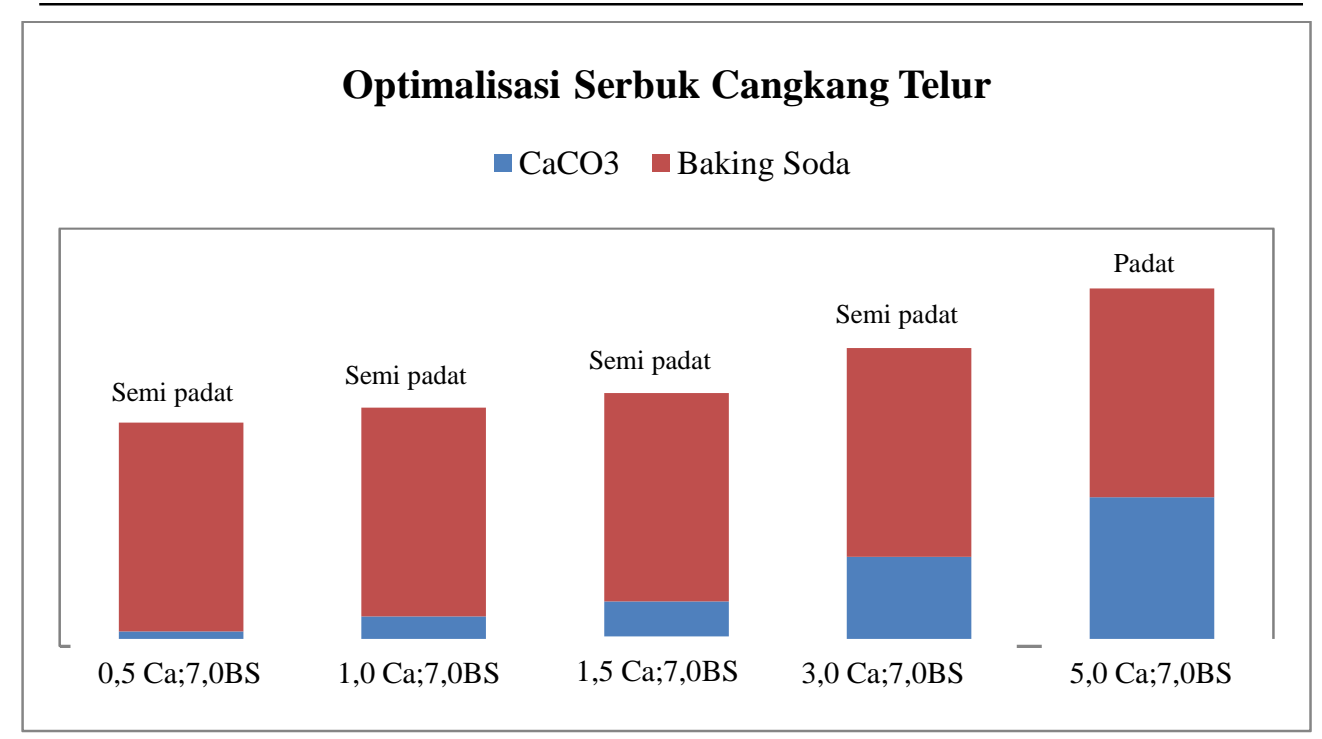

Gambar 3. Optimalisasi Serbuk Cangkang (Kalsium Karbonat) dalam Pembuatan Pasta Komposit

Dari hasil penelitian di atas diperoleh bahwa dalam pembuatan pasta komposit 15,49 gram maka diperlukan kalsium karbonat sebanyak 3,0 gram, baking soda sebanyak 7,0 gram dan gliserin sebanyak $4 \mathrm{~mL}$. Namun, bentuk pasta komposit yang dibuat tidak dapar bertahan dalam 2 minggu karena baking soda dapat larut dalam air, dimana gliserin yang digunakan mengandung air, sehingga bobotnya menurun.

\section{PENUTUP}

\section{Kesimpulan}

Kesimpulan dari penelitian ini adalah berat optimum kalsium karbonat dari cangkang telur untuk produksi pasta komposit sebesar 3 gram dengan perbandingan 3,0 $\mathrm{Ca}: 7,0 \mathrm{BS}$.

\section{Saran}

Saran dari penelitian ini yaitu perlu dilakukan penelitian variasi formula gliserin untuk mengetahui pengaruh viskositasnya dan perlu dilakukan perbandingan kadar kalsium karbonat pada cangkang telur ayam ras dan cangkang telur bebek, juga untuk ukuran partikel serbuk cangkang telur harus lebih halus sekitar 200 mesh. 


\section{DAFTAR PUSTAKA}

Chowdhury, Banani, R., et.al., 2013, Herbal Toothpaste-A Possible Remedy for Oral Cancer,Natural Product, 6: 44-55.

Junaidi, Rido, Syukri Arief, dan Syukri, 2013, Sintesis dan Karakterisasi Komposit yang Berbahan Dasar Kitosan, Silika dan Kalsium Fosfat, Kimia, 2(1): 77-82.

Linardi, Alicia Nadia, 2014, Perbedaan pH Saliva Antara Pengguna Pasta Gigi yang Mengandung Baking Soda dan Pengguna Pasta Gigi yang Mengandung Flour, Skripsi, Makassar: Universitas Hasanuddin Makassar.

Nurlaela, A., et.al., 2014, Pemanfaatan Limbah Cangkang Telur Ayam dan Bebek sebagai Sumber Kalsium untuk Sintesis Mineral Tulang,FPI, 10: $81-85$.

SNI 12-3524, 1995, Pasta Gigi, Jakarta: Dewan Standarisasi Nasional.

Sridianti, Pengertian Gliserin dan Kegunaannya,Artikel Kimia, http://Sridianti. Artikel Kimia.htm/2014/06/ Pengertian-Gliseri- danKegunaannya, Html (Diakses11 Mei 2015).

Zulti, Fifia, 2008, Spektroskopi Inframerah, Serapan Atomik, Serapan Sinar Tampak dan Ultraviolet Hidroksiapatit dari Cangkang telur,Skripsi, Bogor: Institut Pertanian Bogor. 